\title{
KAJIAN ACID NEUTRALIZING CAPACITY PADA MATAAIR KARST NGELENG, PURWOSARI, GUNUNGKIDUL
}

\author{
Hendy Fatchurohman ${ }^{1}$ dan Dr. Tjahyo Nugroho Adji, M.Sc.Tech ${ }^{2}$ \\ ${ }^{1,2}$ Jurusan Geografi Lingkungan, Universitas Gadjah Mada \\ Email : ${ }^{1)}$ hendy_fatchurohman@rocketmail.com
}

\section{INTISARI}

Penelitian ini bertujuan untuk mengetahui karakter kapasitas penetralan asam pada Mataair Ngeleng, Purwosari, Gunungkidul. Data-data yang dikumpulkan dalam penelitian ini diantaranya data debit, curah hujan, $\mathrm{Ca}^{2+}, \mathrm{HCO}_{3}^{-}$, suhu, $\mathrm{pH}$ pada mataair dan rembesan. Sampel diambil dengan memperhatikan perbedaan musim sehingga dapat dibandingkan. Analisis yang digunakan dalam penelitian ini adalah analisis deskriptif, grafis, komparatif, dan regresi. Hasil dari penelitian ini menunjukkan bahwa hubungan antara debit dan kandungan kalsium dalam air pada musim penghujan sangat rendah $\left(r^{2}=0,0068\right)$, dan rendah pada musim kemarau $\left(r^{2}=\right.$ 0,3026). Hubungan debit dengan bikarbonat $\left(\mathrm{HCO}_{3}{ }^{-}\right)$baik pada musim kemarau maupun penghujan masuk dalam kategori sangat rendah $\left(r^{2}=0,0342\right.$ dan 0,0341). Aliran diffuse mendominasi total aliran yang menyuplai debit Mataair Ngeleng dengan persentase aliran dasar (PAD) mencapai $81.06 \%$. Nilai parameter $\mathrm{pH}, \mathrm{Ca}^{2+}$, $\mathrm{HCO}^{-}$, dan suhu pada mataair lebih tinggi daripada nilai yang terukur pada rembesan menunjukkan adanya proses interaksi air dengan batuan karbonat.

Kata kunci : Mataair karst, kapasitas penetralan asam, PAD, interaksi air-batuan karbonat

\begin{abstract}
This research aims to determine the characteristic of Acid Neutralizing Capacity (ANC) in Ngeleng Spring, Purwosari Sub District, Gunungkidul Regency. Several data collected for this research e.g. spring discharge, rainfall, calcium, bicarbonate, temperature, $\mathrm{pH}$, both from the spring or seepage. Analysis that used in this research are descriptive, graphical, comparative, and correlation-regression analysis. The results shows that the correlation between spring discharge and calcium concentration in rainy season was very low $\left(r^{2}=0,0068\right)$, and low class in the dry season $\left(r^{2}=0,3026\right)$. Correlation between spring discharge and bicarbonate $\left(\mathrm{HCO}_{3}{ }^{-}\right)$is classified in very low chategory both in rainy and dry season $\left(\mathrm{r}^{2}=0,0342\right.$ and 0,0341). Diffuse flow dominating total discharge with Diffuse Flow Proportion $(\mathrm{PAD})$ reach $81.06 \%$. Value of the other parameters such as $\mathrm{pH}, \mathrm{Ca}^{2+}, \mathrm{HCO}_{3}^{-}$, and temperature from the spring recorded in higher concentration than value from seepage. This results show that water-rock interaction process occurs
\end{abstract}

Keywords :Karst spring, Acid Neutralizing Capacity, Diffuse Flow Proportion, water-rock interaction. 


\section{PENDAHULUAN}

Karstifikasi sangat berperan besar dalam perkembangan bentuklahan karst. Haryono dan Adji (2004) menjelaskan bahwa dalam proses karstifikasi dipengaruhi oleh dua faktor yaitu faktor pengontrol dan faktor pendorong. Salah satu faktor pengontrol yang berpengaruh dalam proses karstifikasi adalah tingkat kelarutan batuan (Ford dan William, 2007; Haryono dan Adji, 2004; Haryono et al, 2009; Adji, 2005; Adji dan Hariadi, 2009).

Karstifikasi pada batugamping sangat dipengaruhi oleh kemurnian batuan atau besarnya kandungan $\mathrm{CaCO}_{3}$. Jumlah $\mathrm{CO}_{2}$ yang terlarut dalam air juga akan memberikan pengaruh besar dalam tingkat pelarutan yang terjadi pada batuan karbonat. Lebih lanjut proses karstifikasi pada batuan karbonat dirumuskan sebagai berikut :

$$
\mathrm{CaCO}_{3}+\mathrm{H}_{2} \mathrm{O}+\mathrm{CO}_{2} \longrightarrow \mathrm{Ca}^{2+}+2 \mathrm{HCO}_{3}
$$

Karstifikasi pada batuan karbonat memiliki keterkaitan dengan Karst Dynamic System (KDS) atau Sistem Dinamis Karst. Daoxian (2002) menjelaskan bahwa proses karstifikasi merupakan salah satu fase dari siklus karbon global. Karst dikatakan dinamis karena respon alirannya selalu berubah - ubah sesuai musim dan sifat alirannya. Sistem Dinamis Karst terjadi dalam 3 fase yaitu padat, cair, dan gas. Fase padat karst banyak didominasi oleh berbagai jenis batuan karbonat. Fase cair meliputi berbagai unsur kimia yang terlarut dalam air seperti $\mathrm{Ca}^{+}\left(\right.$dan $\left.\mathrm{Mg}^{+}\right), \mathrm{HCO}_{3}{ }^{-}, \mathrm{CO}_{3}{ }^{2-}$, $\mathrm{H}^{+}$dan $\mathrm{CO}_{2}$ terlarut sebagai unsur yang utama. $\mathrm{CO}_{2}$ juga sangat mendominasi pada fase gas.

Beberapa senyawa kimia yang menyusun fase cair Karst Dynamic System adalah alkalinitas. Effendi (2003) menyebutkan bahwa alkalinitas adalah besarnya kuantitas anion dalam air terkait kemampuannya menetralkan kation hidrogen. Lebih sederhananya, alkalinitas adalah kemampuan air dalam menetralkan asam (Acid
Neutralizing Capacity) atau disingkat ANC (Adji, 2013; Adji 2014; Adji 2010; Adji, 2011; Adji, 2015).

Alkalinitas disusun oleh berbagai ion yang terkandung dalam air, namun penyusun yang paling utama adalah bikarbonat $\left(\mathrm{HCO}_{3}{ }^{-}\right)$, karbonat $\left(\mathrm{CO}_{3}{ }^{2-}\right)$ dan hidroksida $\left(\mathrm{OH}^{-}\right)$. Beberapa ion lain seperti borat, fosfat, silikat sebenarnya memiliki peranan namun karena kontribusi asam organik ini lemah pada ANC maka keberadaanya diabaikan (Chandler dan Bisogni, 1999; Adji et al, 2009; Adji et al, 2007; Adji and Rahmawati, 2010; Hariadi dan Adji, 2009).

Pembentukan bentuklahan karst melalui proses pelarutan sangat erat kaitannya dengan siklus karbon (Adji and Haryono, 1999; Adji et al, 1999). Salah satu karakter kimia mataair karst yang dapat diamati adalah alkalinitas. Alkalinitas mencerminkan kemampuan air dalam menetralkan asam (Acid Neutralizing Capacity). Kandungan karbon yang ada di perairan diwakili oleh alkalinitas dari perairan itu sendiri. Tujuan yang ingin dicapai dalam penelitian ini adalah :

1) Mengetahui hubungan antara aliran dengan kandungan $\mathrm{Ca}^{2+}$ dan $\mathrm{HCO}_{3}^{-}$di Mataair Ngeleng.

2) Mengetahui variasi temporal Acid Neutralizing Capacity (ANC) dalam bentuk $\mathrm{HCO}_{3}$ - pada Mataair Ngeleng.

3) Mengetahui perbandingan karakter Acid Neutralizing Capacity yang keluar melalui mataair dan melalui rembesan.

Hasil dari penelitian ini diharapkan dapat memberikan manfaat baik dalam bidang ilmu pengetahuan maupun bidang aplikatif. Secara teoritis, hasil penelitian ini diharapkan mampu menjadi salah satu referensi terkait dengan penelitian mengenai mataair karst. Kajian mengenai kapasitas penetralan asam ini diharapkan juga dapat menjadi salah satu acuan 
dalam pengelolaan mataair kawasan karst terkait sifat aliran dan hidrogeokimianya.

Data-data yang dikumpulkan dalam penelitian ini diantaranya data debit, curah hujan, $\mathrm{Ca}^{2+}, \mathrm{HCO}_{3}{ }^{-}$, suhu, $\mathrm{pH}$ pada mataair dan rembesan. Data curah hujan dan tinggi muka air dikumpulkan dengan menggunakan pencatat curah hujan dan pencatat tinggi muka air otomatis. Sedangkan data $\mathrm{Ca}^{2+}, \mathrm{HCO}_{3}^{-}$, suhu, dan $\mathrm{pH}$ diambil secara sitematis selama 24 jam dengan jeda waktu pengambilan setiap 2 jam sekali. Sampel diambil dengan memperhatikan perbedaan musim sehingga dapat dibandingkan. Analisis yang digunakan dalam penelitian ini

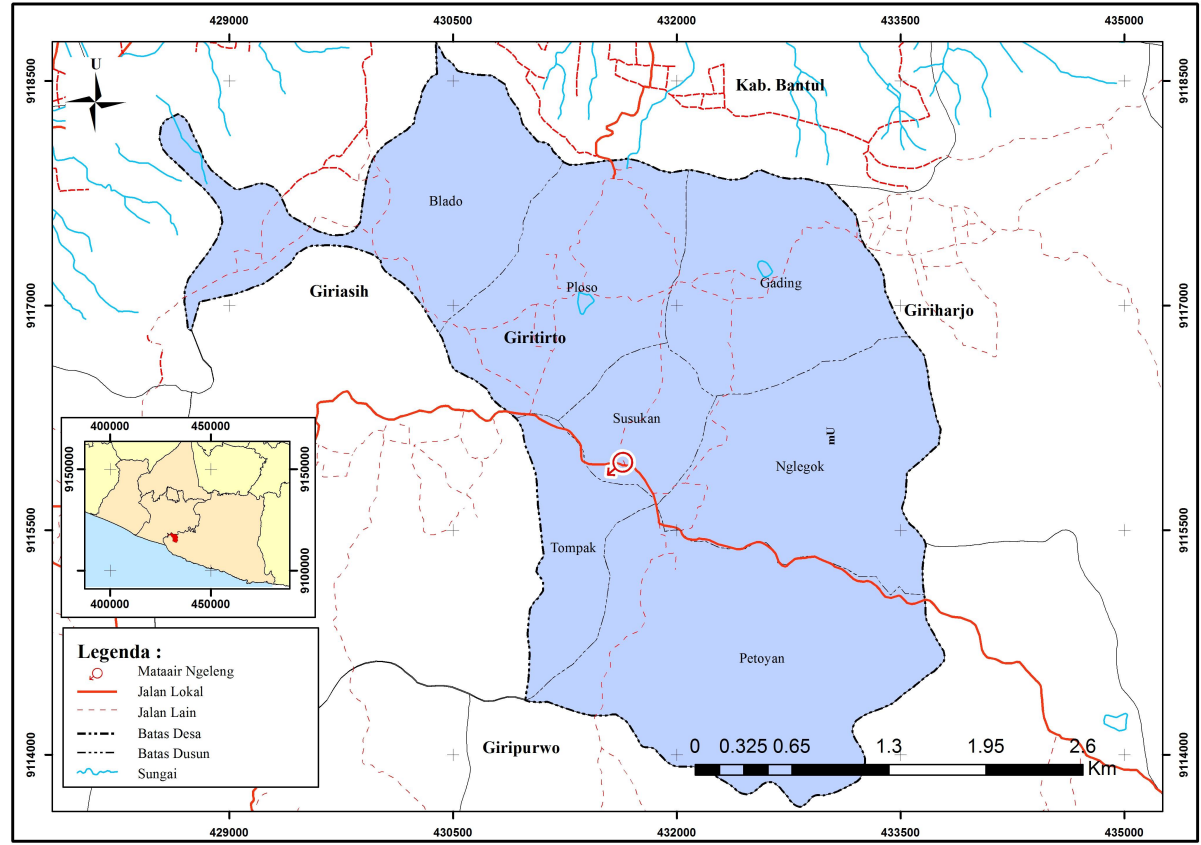

Gambar 1. Peta Lokasi Penelitian

adalah analisis deskriptif, grafis, komparatif, dan regresi. Data aliran diolah untuk mengetahui karakteristik aliran dan menghitung konstanta resesi. Nilai konstanta resesi aliran diperoleh dari rumus :

$$
\mathrm{Q}_{\mathrm{t}}=Q_{0} \cdot e^{-\alpha \cdot t}
$$

Sedangkan untuk $(\alpha)$ Alpha aliran atau koefisien resesi aliran, didapatkan dengan rumus.

$\alpha=\left(\mathrm{LN} \mathrm{Q}_{0}-\mathrm{LN} \mathrm{Q}_{\mathrm{t}}\right) /\left(\mathrm{T}_{\mathrm{t}}-\mathrm{T}_{0}\right)$ atau

$$
\alpha=\frac{\left(\operatorname{Ln} Q_{0}-\operatorname{Ln} Q_{t}\right)}{T_{t}-T_{0}}
$$

Cara yang digunakan dalam pemisahan aliran dasar menggunakan model yang dikembangkan oleh Eckhardt (2005), yaitu automated base flow separation by digital filtering method.

\section{HASIL DAN PEMBAHASAN}

\section{Hubungan antara aliran dengan kandungan} $\mathrm{Ca}^{2+}$ dan $\mathrm{HCO}^{3-}$

Nilai debit yang didapat akan dibandingkan degan tinggi muka air untuk membuat hubungan keduanya dalam bentuk stage discharge rating curve. Pengukuran debit dilakukan mulai Bulan Oktober 2012 s.d. Juni 2013 pada berbagai variasi aliran yang ditunjukkan dalam tabel 1 berikut.

\section{Tabel 1. Hasil Pengukuran Debit Aliran Mataair Ngeleng}

Waktu TMA (m) Debit (lt/dt)

\begin{tabular}{ccc}
\hline 13 Oktober 2012 & 0.045 & 5.20 \\
\hline 21 Oktober 2012 & 0.071 & 6.90
\end{tabular}




\begin{tabular}{ccc} 
28 Oktober 2012 & 0.090 & 9.50 \\
\hline 10 Nopember 2012 & 0.028 & 3.60 \\
\hline 21 Nopember 2012 & 0.045 & 4.28 \\
\hline 23 Februari 2013 & 0.063 & 6.20 \\
\hline 3 maret 2013 & 0.048 & 5.40 \\
\hline 09 Maret 2013 & 0.089 & 9.20 \\
\hline 17 Juni 2013 & 0.054 & 5.80
\end{tabular}

Sumber : Pengukuran Lapangan 2012-2013

Berdasarkan hasil pengukuran tersebut dibuat kurva regresi antara keduanya yang menghasilkan hubungan :

$y=94.591 x+0.6292$

Keterangan :

$\mathrm{y}:$ debit aliran (liter/detik)

$\mathrm{x}$ : tinggi muka air (meter)

Hasil persamaan regresi menunjukkan nilai koefisien determinasi yang sangat tinggi yaitu 0,9655 . Nilai tersebut menunjukkan bahwa kedua variabel memiliki hubungan yang positif dan signifikan.

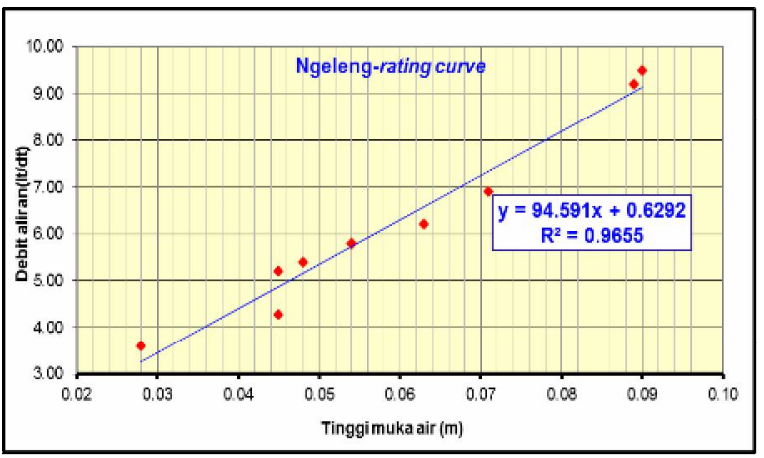

Gambar 2. Stage Discharge Rating Curve Mataair Petoyan

(Sumber : Olah Data, 2013)

Selanjutnya rumus regresi rating curve digunakan untuk menghitung debit sesuai dengan tinggi muka air yang tercatat. Melalui kurva hidrograf ( Gambar 2 ) dapat dilihat variasi aliran Mataair Ngeleng selama Bulan Oktober 2012 hingga April 2013. Berdasarkan grafik, paling tidak terdapat 10 (sepuluh kejadian banjir yang terekam. Banjir terbesar terjadi pada Bulan Januari dimana curah hujan mencapai

puncaknya. Sifat mataair yang didominasi aliran diffuse menyebabkan mataair masih mempunyai simpanan aliran dasar yang besar, sehingga tetap mengalir selama musim kemarau. Jumlah debit memang menurun saat musim kemarau namun masih dapat digunakan untuk membantu pemenuhan kebutuhan air bagi penduduk di sekitar Mataair Ngeleng.

Data rating curve dan data hidrograf yang disajikan dalam Gambar 1 dan 2 menunjukkan karakter aliran yang bersifat laminer seperti sungai permukaan. Karakter tersebut menunjukkan bahwa komponen aliran yang bersifat diffuse lebih dominan dalam memberikan imbuhan terhadap debit aliran mataair. Akan tetapi, hal tersebut juga harus dibuktikan secara lebih terperinci karena hidrograf tidak menunjukkan dominasi komponen aliran yang mengimbuh mataair. Akuifer karst merupakan akuifer dengan sifat yang unik dan memiliki karakter yang berbeda dengan aliran permukaan dalam pelepasan komponen alirannya.

Schulz (1976) mengenalkan model resesi untuk menghitung konstanta resesi aliran. Model yang diperkenalkan tersebut adalah model tangki atau tank model yang dapat menghitung nilai konstanta resesi saluran conduit $(\mathrm{Kc})$, konstanta resesi aliran antara / fissure (Ki), dan konstanta aliran dasar / baseflow (Kb). Analisis dilakukan pada beberapa kejadian banjir yang memenuhi syarat untuk dilakukan perhitungan konstanta resesi. Banjir yang digunakan dipilih berdasarkan lamanya waktu dari puncak kejadian banjir sampai kembali ke aliran normal $(\mathrm{Tb}=$ time to baseflow). Kejadian banjir dengan nilai $\mathrm{Tb}$ yang terlalu singkat tidak digunakan dalam perhitungan karena tidak valid secara matematis apabila diukur konstanta resesinya (Schulz, 1976).

Aliran antara yang terekam dalam periode banjir memiliki variasi pasokan yang cukup tinggi, ditunjukkan dengan julat nilai $\mathrm{Ki}$ yang berkisar antara 0,4475 - 0,9782 dengan nilai rata- rata sebesar 0,7481 . Sementara itu nilai aliran dasar mendominasi pasokan saat terjadi banjir yang ditunjukkan dengan nilai $\mathrm{Kb}$ antara 0,9497 - 0,9971 dengan nilai rata-rata 
sebesar 0,9818. Aliran yang berasal dari saluran (conduit) hanya ditemukan pada beberapa kejadian banjir dengan debit yang besar. Aliran conduit memiliki konstanta rata-rata sebesar 0,5526 . Bukti adanya dominasi aliran dasar ( baseflow ) pada Mataair Ngeleng juga diperkuat dengan nilai time to peak (Tp) dan time to base (Tb) seperti yang ditunjukkan dalam Tabel 2. Tp adalah lama waktu yang dibutuhkan dari debit normal untuk mencapai banjir puncak pada mataair. Nilai Tp Mataair Ngeleng berkisar antara 0,5- 7 jam dengan waktu rata-rata 3.60 jam. Sedangkan waktu yang diperlukan dari debit puncak untuk kembali ke aliran dasar berkisar antara 0.5-8 jam dengan waktu rata-rata 9.3 jam. Berdasarkan nilai tersebut diketahui bahwa perbedaan waktu antara $\mathrm{Tp}$ dan $\mathrm{Tb}$ tidak terlalu besar. Hal tersebut mengindikasikan bahwa penyuplai aliran saat terjadi banjir didominasi oleh aliran dasar.

Tabel 2. Konstanta Resesi, Tp dan Tb Hidrograf Banjir Terpilih Mataair Ngeleng

\begin{tabular}{ccccccccc} 
& Tanggal & Debit Puncak & Kb & Ki & Kc & Tp & Tb & \% baseflow \\
\hline Banjir 1 & $18 / 10 / 12$ & 21.16 & 0.9790 & 0.7354 & - & 1 & 4.5 & 38.05 \\
\hline Banjir 2 & $10 / 11 / 12$ & 24.75 & 0.9921 & 0.9782 & - & 0.5 & 46 & 20.04 \\
\hline Banjir 3 & $22 / 11 / 12$ & 22.48 & 0.9694 & 0.7465 & - & 5.5 & 5 & 49.44 \\
\hline Banjir 4 & $23 / 11 / 12$ & 22.48 & 0.9828 & 0.4475 & - & 6 & 4 & 53.91 \\
\hline Banjir 5 & $10 / 12 / 12$ & 44.14 & 0.9936 & 0.7605 & 0.7880 & 0.5 & 7 & 11.83 \\
\hline Banjir 6 & $21 / 12 / 12$ & 23.14 & 0.9913 & 0.7935 & 0.7935 & 4 & 4 & 23.75 \\
\hline Banjir 7 & $28 / 12 / 12$ & 24.66 & 0.9832 & 0.7937 & 0.0260 & 3.5 & 8 & 28.37 \\
\hline Banjir 8 & $31 / 12 / 12$ & 48.49 & 0.9497 & 0.7346 & 0.6029 & 4 & 7 & 26.74 \\
\hline Banjir 9 & $07 / 01 / 13$ & 18.03 & 0.9971 & 0.7429 & - & 4 & 7 & 41.19 \\
\hline Banjir 10 & $03 / 02 / 13$ & 24.56 & 0.9798 & - & - & 7 & 0.5 & 37.93 \\
\hline & rata-rata & & $\mathbf{0 . 9 8 1 8}$ & $\mathbf{0 . 7 4 8 1}$ & $\mathbf{0 . 5 5 2 6}$ & $\mathbf{3 . 6 0}$ & $\mathbf{9 . 3 0}$ & $\mathbf{3 3 . 1 2}$
\end{tabular}

Sumber : Pengukuran dan Analisis Data Tahun 2013

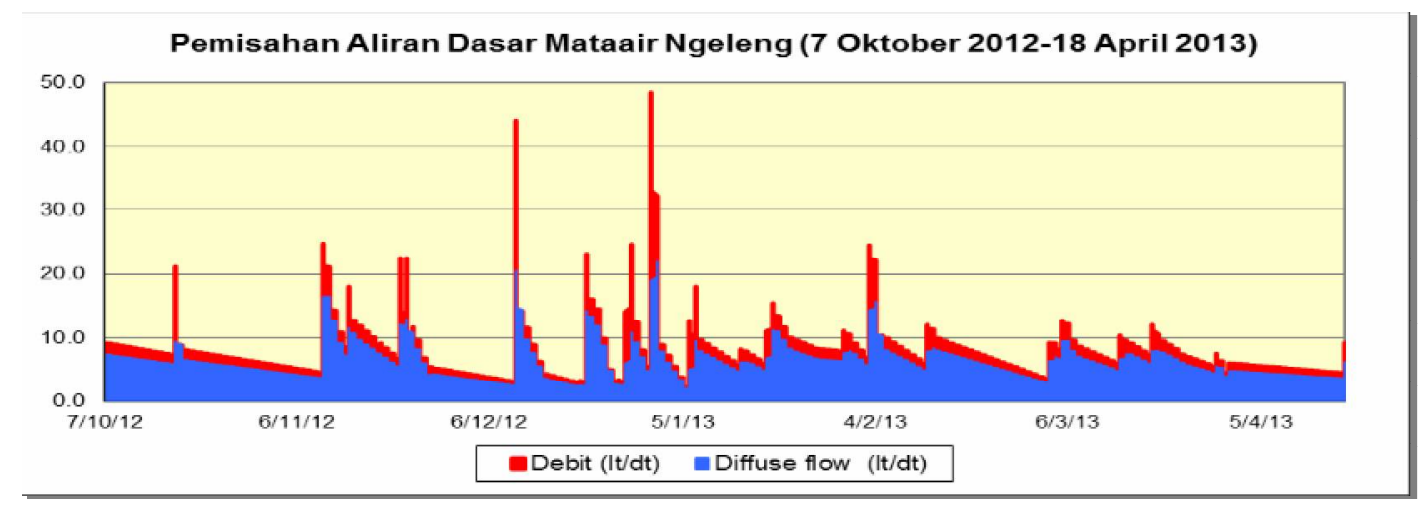

Gambar 4. Pemisahan Aliran Dasar Mataair Ngeleng

( Olah Data, 2013) 
Appelo dan Postma (1994) menyebutkan bahwa terdapat tiga fase yang memiliki keterkaitan terhadap proses water-rock interaction. Ketiga proses tersebut adalah kondisi air tidak jenuh (undersaturated), kondisi seimbang (equilibrium), dan kondisi air sudah jenuh (supersaturated). Pada kondisi tidak jenuh, air masih dapat melarutkan batuan karbonat yang dilaluinya. Pelarutan terhenti pada fase kesetimbangan, dan terjadi pengendapan (precipitation) saat kondisi air sudah jenuh. Pada sistem terbuka (open system) dengan kandungan karbondioksida yang lebih banyak dalam air, maka pelarutan batugamping akan lebih intensif. Semakin intensif pelarutan maka kandungan $\mathrm{Ca}^{2+}$ dan $\mathrm{HCO}_{3}{ }^{-}$dalam air akan semakin banyak.

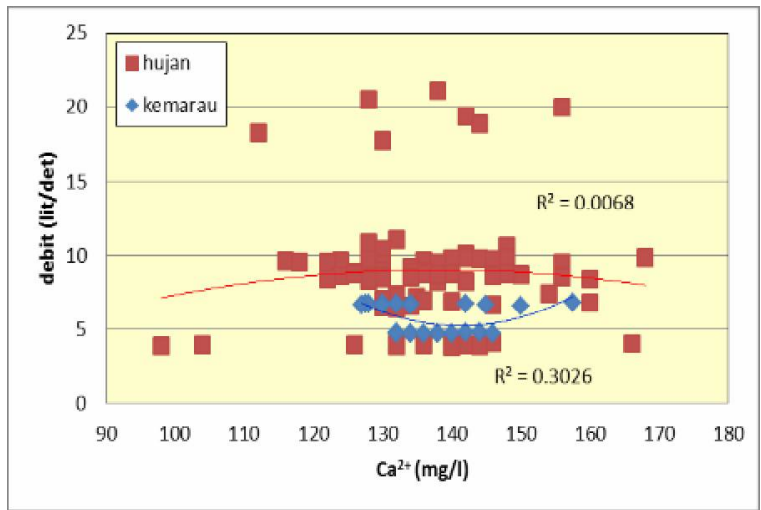

Gambar 5. Hubungan kalsium ( $\mathrm{Ca}^{2+}$ ) dengan debit aliran

( Olah data, 2013)

Gambar di atas menunjukkan tingkat hubungan antara debit dan kandungan kalsium dalam air pada musim penghujan sangat rendah, sedangkan pada musim kemarau masuk dalam kategori rendah (Sugiyono, 2007). Nilai kandungan kalsium terlarut dalam air cukup tinggi meskipun hubungannya dengan variabel debit rendah. Dominasi aliran diffuse menyebabkan air dalam kondisi saturated atau jenuh terhadap batuan karbonat namun dapat berubah begitu agresif ketika terjadi hujan diatas $100 \mathrm{~mm}^{2}$ selama beberapa jam. Saat terjadi banjir puncak pada aliran diffuse maka tekanan parsial gas karbondioksida akan semakin besar sehingga pelarutan lebih intensif ( Adji, 2009).

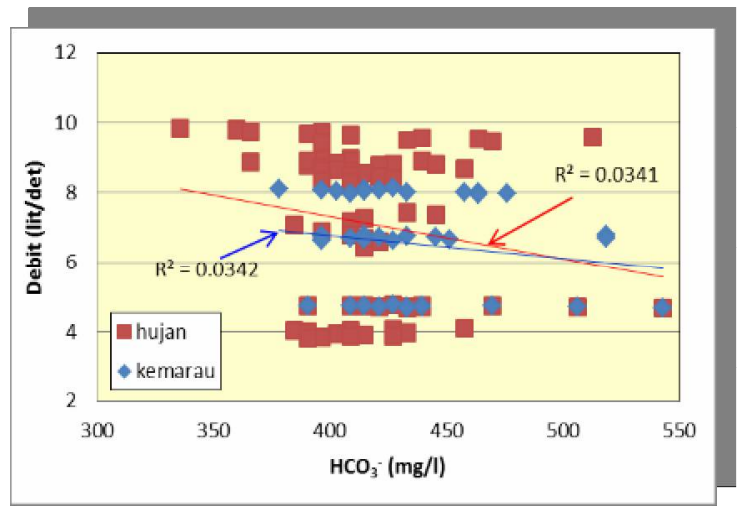

Gambar 6. Hubungan Debit dengan $\mathrm{HCO}_{3}{ }^{-}$ pada Mataair Ngeleng

( Olah Data, 2013)

Secara statistik hubungan antara bikarbonat dengan debit aliran baik pada musim penghujan maupun musim kemarau masuk ke dalam kategori sangat rendah. Julat nilai hubungan koefisien korelasi antara 0,00 0,199 dikatakan memiliki hubungan yang sangat rendah (Sugiyono, 2007). Debit aliran yang cenderung lebih tinggi dan dinamis pada musim penghujan serta kejadian banjir yang lebih besar dan banyak membuat sebaran nilai bikarbonat pada musim penghujan lebih bervariasi. Berbagai macam faktor di lapangan seperti perbedaan jumlah karbondioksida di sekitar tubuh air serta intensitas pelarutan yang terjadi. Dinamika kondisi di lapangan tersebut menyebabkan hasil pengukuran tidak selalu sesuai dengan hipotesis yang sudah ada. Nilai hubungan antara debit dan bikarbonat juga tidak selalu linier karena berbagai faktor yang menyebabkan sebaran nilai bikarbonat yang terukur menjadi beragam.

2) Variasi Temporal Acid Neutralizing Capacity (ANC) dalam Bentuk $\mathrm{HCO}_{3}{ }^{-}$pada Mataair Ngeleng

Kapasitas penetralan asam diwakili oleh nilai alkalinitas dalam mataair, yang direpresentasikan dalam bentuk bikarbonat sebagai ion karbon anorganik yang paling banyak terdapat dalam air. Dalam kondisi 
perairan alami, alkalinitas berasal dari spesies karbondioksida yang terlarut dalam air.

Berdasarkan Gambar 7 dapat dilihat variasi temporal bikarbonat pada Mataair Ngeleng. Rentang nilai bikarbonat pada musim penghujan cenderung lebih bervariasi daripada musim kemarau. Fluktuasi debit yang lebih tinggi saat musim penghujan mempengaruhi kandungan bikarbonat terlarut dalam air. Disebabkan oleh volume air yang lebih tinggi maka kandungan bikarbonat akan cenderung menurun karena konsentrasinya dalam air akan turun seiring kenaikan debit aliran. Pada dasarnya, saat terjadi hujan yang melarutkan batuan karbonat, nilai bikarbonat pada air juga akan naik.

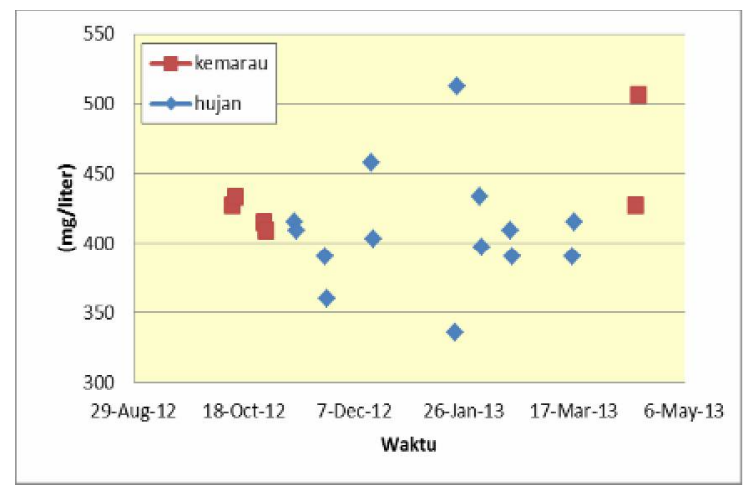

\section{Gambar 7. Variasi Nilai HCO3- berdasarkan Musim \\ (Olah Data,2013)}

Akan tetapi, kenaikan nilai bikarbonat tidak terjadi secara langsung setelah kejadian hujan. Hujan yang jatuh di mataair atau daerah tangkapan mataair, tidak seluruhnya menjadi imbuhan aliran mataair. Waktu tempuh saat hujan turun hingga masuk menjadi debit aliran juga tidak terjadi secara sesaat. Sifat mataair yang didominasi aliran diffuse juga berpengaruh terhadap kecepatan air permukaan atau yang tersimpan di daerah tangkapan untuk menjadi debit aliran. Sifat aliran diffuse berbeda dengan aliran conduit yang memiliki respon cepat terhadap hujan.

Variasi temporal nilai $\mathrm{pH}$ Mataair Ngeleng cenderung konstan dengan julat nilai $\mathrm{pH}$ yang tidak terlalu tinggi. Nilai $\mathrm{pH}$ yang tercatat selama penelitian berkisar antara 5,38,23 . Kemampuan dalam melawan perubahan $\mathrm{pH}$ ketika terdapat masukan asam ini disebut pula alkalinitas atau Acid Neutralizing Capacity. Kemampuan menetralkan asam ini berperan sebagai penyangga perairan terhadap perubahan $\mathrm{pH}$ ( buffer capacity). Ketika perairan memiliki kemampuan untuk mempertahankan nilai $\mathrm{pH}$ agar tidak berubah secara drastis ketika mendapat masukan asam atau basa, maka dikatakan perairan tersebut memiliki kapasitas penyangga yang cukup. Perairan dengan nilai alkalinitas yang tinggi akan sulit mengalami perubahan $\mathrm{pH}$ secara drastis.

\section{3) Karakter Acid Neutralizing Capacity yang} keluar melalui mataair dan melalui rembesan.

Melihat perbandingan parameter terukur antara mataair dengan rembesan dapat dilihat bahwa dominasi aliran diffuse pada mataair menyebabkan terjadinya proses waterrock interaction. Pelepasan aliran diffuse yang telah jenuh dengan batuan karbonat menyebabkan nilai kalsium, $\mathrm{pH}$ dan bikarbonat pada mataair lebih besar dari rembesan. Nilai suhu yang tercatat pada rembesan masih cenderung normal dan bukan pada kondisi hidrotermal sehingga tidak merubah kesetimbangan nilai $\mathrm{pH}$.

Tabel 3. Perbandingan nilai $\mathrm{pH}, \mathrm{HCO}_{3}{ }^{-}, \mathrm{Ca}^{2+}$ dan Suhu antara Mataair dengan Rembesan

\begin{tabular}{ccc} 
& Mataair & Rembesan \\
\hline \multirow{2}{*}{$\mathrm{pH}$} & 6.92 & 6.82 \\
\cline { 2 - 3 } & 7.10 & 6.63 \\
\hline \multirow{2}{*}{$\mathrm{HCO}_{3}{ }^{-}(\mathrm{mg} / \mathrm{l})$} & 359.98 & 311.17 \\
\cline { 2 - 3 } & 384.39 & 329.47 \\
\hline \multirow{2}{*}{$\mathrm{Ca}^{2+}(\mathrm{mg} / \mathrm{l})$} & 124.00 & 118.00 \\
\cline { 2 - 3 } & 130.00 & 106.00 \\
\hline \multirow{2}{*}{ Suhu $\left({ }^{0} \mathrm{C}\right)$} & 26 & 25 \\
\cline { 2 - 3 } & 25 & 25
\end{tabular}

Sumber : Pengukuran Lapangan, 2013. 


\section{KESIMPULAN}

- $\quad$ Secara statistik, tidak ada hubungan yang kuat antara aliran dengan kandungan kalsium dan bikarbonat. Aliran diffuse mendominasi total aliran yang menyuplai debit Mataair Ngeleng dengan PAD mencapai $81,06 \%$.

- $\quad$ Variasi Temporal Acid Neutralizing Capacity (ANC) dalam Bentuk $\mathrm{HCO}_{3}^{-}$pada Mataair Ngeleng memiliki karakter yang berbeda sesuai musim. Pada musim penghujan rentang nilai bikarbonat lebih bervariasi dibandingkan musim kemarau karena fluktuasi debit yang lebih tinggi.

- $\quad$ Nilai parameter $\mathrm{pH}, \mathrm{Ca}^{2+}, \mathrm{HCO}^{-}$, dan suhu pada mataair lebih tinggi daripada nilai yang terukur pada rembesan. Tingginya nilai $\mathrm{pH}, \mathrm{Ca}^{2+}, \mathrm{HCO}^{-}$, dan suhu pada mataair dibandingkan dengan rembesan menunjukkan adanya proses water-rock interaction.

\section{DAFTAR PUSTAKA}

Adji, T. N., 2010. Variasi Spasial-Temporal Hidrogeokimia dan Sifat Aliran Untuk Karakterisasi Sistem Karst Dinamis Di Sungai Bawah Tanah Bribin, Kabupaten Gunungkidul, DIY. Desertasi. Fakultas Geografi, Universitas Gadjah Mada.

Adji, T. N., 2010. Spatial and Temporal Variation of Hydrogeochemistry and Karst Flow Properties to Characterize Karst Dynamic System in Bribin Underground River, Gunung Kidul Regency, DIY Province Java, Indonesia. Summary, Dissertation in Geography Study Program. Graduate School of Geography, Gadjah Mada University, Yogyakarta

Adji, T.N. 2012, Wet Season Hydrochemistry of Bribin River in Gunung Sewu Karst,
Indonesia, Environmental Earth Sciences, Vol. 67:1563-1572 pp

Adji, T.N. dan Haryono, E., 1999. Konflik Antara Pemanfaatan Batugamping dan Konservasi Sumberdaya Air Das Bribin di Wilayah Karst Gunung Sewu, Makalah Lokakarya Nasional Menuju Pengelolaan Sumberdaya Wilayah Berbasis Ekosistem Untuk Mereduksi Konflik Antar Daerah, Yogjakarta, , Fakultas Geografi, Universitas Gadjah Mada, September 1999

Adji, T.N., 2005, Agresivitas Airtanah Karst Sungai Bawah Tanah Bribin, Gunung Sewu, Indonesian Cave and Karst Journal, Vol. 1 No1, HIKESPI

Adji, T.N., 2011, Upper catchment of Bribin underground river hydrogeochemistry (Gunung Sewu Karst, Gunung Kidul, Java, Indonesia) Proceeding of Asian TransDisclipinary Karst Conference, Yogyakarta

Adji, T.N., 2013, Hubungan Karakter Aliran dan Sifat Kimia Mataair Petoyan Untuk Karakterisasi Akuifer Karst, Hibah Dana Masyarakat Fak. Geografi UGM

Adji, T.N., Haryono, E., Woro, S, 1999, Kawasan Karst dan Prospek Pengembangannya di Indonesia, Seminar PIT IGI di Universitas Indonesia, 26-27 Oktober 1999

Adji, T.N., Rahmawati, N., 2010, The Contribution of $\mathrm{CO}_{2}$ Content in Rainfall to Dissolution Process in Karst Area (Case Study In Bribin Underground River), The Proceeding of Technology cooperation and economic benefit of reduction of $\mathrm{GHG}$ emissions in Indonesia" held on 1-2 November 2010 in Hamburg

Appelo, C.A.J., Postma, D., 1994. Geochemistry, groundwater and pollution, Rotterdam, 536p : A.A. Balkema.

Chandler, D.G., dan Bisogni Jr., J.J.1999. The use of alkalinity as a conservative tracer in a study of near-surface hydrologic change in tropical karst. Journal of Hydrology. 216 (1999) 172-182 
Cherng ,A. Maria, Takagi, Shozo and Chow, Laurence C. 2010. Acid Neutralization Capacity of a Tricalcium Silicate-Containing Calcium Phosphate Cement as an Endodontic Material. Journal of Research of the National Institute of Standards and Technology. 471-476 (2010).

Daoxian, Y. 2002. The Carbon Cycle in Karst, IGCP Report. Institute of Karst Geology. Guilin.

Eckhardt, K, 2005. How to construct recursive digital filters for baseflow separation. Hydrological Processes No 19, 507-515.

Effendi, H. 2003. Telaah Kualitas Air Bagi Pengelolaan Sumberdaya dan Lingkungan Perairan. Yogyakarta : Kanisius.

Ford, D.C. dan P.W. Williams. 2007. Karst Geomorphology and Hydrology. Chicester : John Willey and Sons.

Hariadi, B., Adji, T.N., 2009, Variasi Temporal Hidrogeokimia Tetesan dari Ornamen Drapery di Dalam Gua Gilap di Kawasan Karst Gunungsewu, Kabupaten Gunungkidul, DIY, Gunung Sewu-Indonesian Cave and Karst Journal, Vol 5 No 1, April 2009

Haryono, E. dan Adji, T.N. 2004. Geomorfologi dan Hidrologi Karst. Yogyakarta : Kelompok Studi Karst Fakultas Geografi UGM.

Jankowski, J. 2002. Short Course Note Hydrogeochemistry. New South Wales : UNSW Groundwater Center.

Schulz, E.F., 1976. Problems in Applied Hydrology. Colorado : Water Resources Publication

Waltham, Antony C.; Smart, Peter L.; Friedrich, H.; Atkinson, Timothy C. 1985. Exploration of Caves for Rural Water Supplies in The Gunung Sewu Karst Java. Journal Annales de la Societe Geologique de Belgique, T 108-1985, pp. 27-31.

White, William B., 1988. Geomorphology and Hydrology of Karst Terrains, Oxford University Press. New York.

White, William B., 2004. Conceptual models for karstic aquifers. Speleogenesis and Evolution of Karst Aquifers, 1 (1) January 2003, p.2. 